\title{
PEMANFAATAN LIMBAH FLY ASH BATUBARA SEBAGAI KOAGULAN DENGAN KONSEP REVERSE LOGISTICS
}

\author{
Ali Abidin, Eko Budi Leksono* \\ Program Studi Teknik Industri, Fakultas Teknik, Universitas Muhammadiyah Gresik \\ Email: aliabidin23@gmail.com; eko_budileksono@umg.ac.id
}

Artikel masuk : 16-11-2020

Artikel direvisi : 12-02-2021
${ }^{*}$ Penulis Korespondensi

Artikel diterima : 24-02-2021

\begin{abstract}
Abstrak -- Proses produksi Pembangkit Listrik Tenaga Uap yang menggunakan batubara sebagai sumber energi pembakarannya, menghasilkan limbah berupa fly ash dan buttom ash yang tergolong Bahan Beracun dan Berbahaya (B3). Apabila limbah batubara tidak dikelola dengan baik, akan menyebabkan pencemaran lingkungan. PT Petrokimia Gresik memiliki pembangkit listrik dengan dua unit boiler yang menggunakan batubara sebagai sumber energi pembakaran, dengan kapasitas 32 megawatt. Penelitian ini bertujuan memanfaatkan limbah fly ash batubara yang dihasilkan dari Utilitas Batubara (UBB) yang berjumlah 20 ton per hari. Data yang diperlukan dalam penelitian ini yaitu data limbah fly ash batubara dan data kebutuhan koagulan yang berasal dari data produksi. Dengan menggunakan metode reverse logistics, fly ash batubara didaur ulang menjadi koagulan padat untuk dijadikan bahan masukan di unit effluent treatment yang kemudian dapat menghasilkan air bersih untuk diproses menjadi air demin sebagai Boiler Feed Water di UBB. Fly ash dijadikan koagulan dengan cara mereaksikannya menggunakan Asam sulfat (H2SO4). Berdasarkan hasil penelitian, Rasio pencampuran optimum antara fly ash kadar Al2O3 sebesar 20,56\% dengan H2SO4 1:1 dalam pembuatan koagulan didapatkan rasio 1:2. Dosis optimum pemakaian koagulan dalam penelitian ini pada air limbah di TK 6616 (neutralis water) yaitu sebesar $0,5 \mathrm{~g} / \mathrm{L}(500 \mathrm{ppm})$ dengan penurunan turbiditas sebesar 98,68\% dan penurunan TSS sebesar 97,41\%. Kemudian, koagulan hasil pengelolaan dijadikan bahan masukkan di unit effluent treatment PT Petrokimia Gresik, sehingga dapat membentuk sistem closed loop pada aliran proses produksi. Potensi keuntungan dari penerapan hasil penelitian ini sebesar $R p$ 49.394.250 per hari.
\end{abstract}

Kata kunci: Batubara; Closed Loop; Fly Ash; Koagulan; Lingkungan; Reverse Logistics

\begin{abstract}
The production process of a Steam Power Plant, which uses coal as its combustion energy source, produces waste in the form of fly ash and bottom ash, which are classified as Toxic and Hazardous Materials (B3). If coal waste is not managed properly, it will cause environmental pollution. PT Petrokimia Gresik has a power plant with two boiler units that use coal as a source of combustion energy, with a capacity of 32 megawatts. This study aims to utilize coal fly ash waste generated from Coal Utilities (UBB), amounting to 20 tons per day. The data needed in this research are coal fly ash waste data and coagulant requirement data derived from production data. By the reverse logistic method, coal fly ash is recycled into solid coagulants to be used as input material in the effluent treatment unit, which can then produce clean water to be processed into Demin water as Boiler Feed Water in UBB. Fly ash is used as a coagulant by reacting it with sulfuric acid (H2SO4). Based on the study results, the optimum mixing ratio between fly ash with Al2O3 content was $20.56 \%$ with $\mathrm{H} 2 \mathrm{SO} 4$ 1: 1 in the manufacture of coagulants obtained a ratio of 1:2. The optimum dose for the use of coagulants in this study on wastewater in TK 6616 (neutralize water) was $0.5 \mathrm{~g} / \mathrm{L}$ (500 ppm) with a decrease in turbidity of $98.68 \%$ and a decrease in TSS of $97.41 \%$. Then, the coagulant results from the management are used as input material in the effluent treatment unit of PT Petrokimia Gresik so that it can form a closed-loop system in the flow of the production process. The potential profit from the application of the results of this study is IDR 49,394,250 per day.
\end{abstract}

Keywords: Coal; Closed Loop; Fly Ash; Coagulants; Environment; Reverse Logistics 


\section{PENDAHULUAN}

Isu lingkungan hari ini menjadi pembahasan hangat di seluruh dunia. Hampir seluruh sektor memasukan isu lingkungan ke dalam rencana pembangunannya, tak terkecuali sektor industri. Perhatian ini tak terlepas dari kondisi alam yang mulai mengkhawatirkan, dibuktikan dengan banyaknya fenomena kerusakan alam yang ditimbulkan oleh eksploitasi manusia terhadap alam.

Dimulainya era renaissance pada abad ke14 di Eropa yang kemudian melahirkan manusia modern yang bertumpu pada filsafat antroposentrisme. Antroposentrisme merupakan teori tentang etika lingkungan yang berpandangan bahwa manusia adalah pusat dari sistem alam dan merupakan entitas yang mempunyai nilai tertinggi, sedangkan entitas lain ada hanya untuk pemenuhan hidup manusia (Keraf, 2010). Renaissance yang awalnya merupakan gerakan budaya, dalam perjalanannya melahirkan revolusi industri pada abad ke-18 yang ditandai dengan penemuan mesin uap sebagai penggerak peralatan produksi maupun transportasi. Revolusi industri bermula di Inggris yang kemudian menyebar ke seluruh dunia dan melahirkan teknologi guna mempermudah manusia dalam hal pekerjaan (Fajariah \& Suryo, 2020).

Dalam perkembangannya, sumber energi penggerak produksi maupun transportasi beralih dari semula mengandalkan tenaga manusia dan hewan, ke energi fosil seperti minyak bumi dan batubara. Energi fosil memerlukan waktu jutaan tahun dalam proses pembentukannya dan kini manusia sangat bergantung pada sumber energi yang tidak bisa diperbaharui (non-renewable) (Baiquni, 2009). Selain merupakan energi yang tidak dapat diperbaharui, dalam proses pemanfaatan, penggunaan energi fosil terutama batubara juga menghasilkan limbah yang berpotensi mencemari lingkungan.

PT. Petrokimia Gresik merupakan perusahaan pupuk dan bahan kimia yang juga memiliki pembangkit listrik tenaga uap air mandiri yang disebut Utilitas Batubara (UBB) dengan menggunakan batubara sebagai sumber energi pembakaran. Dalam prosesnya, pembakaran batubara di UBB menghasilkan limbah sisa pembakaran. Sejauh ini pengelolaan limbah fly ash diserahkan kepada pihak ke-3 yang membutuhkan biaya tinggi dan sebagian di tempatkan di landfill. Hal ini dapat berakibat pada pencemaran lingkungan, baik pencemaran udara, tanah maupun air tanah. Selain itu, dapat berdampak pada masalah sosial dengan adanya pencemaran lingkungan.
Hasil pembakaran batubara menghasilkan limbah kategori Bahan Beracun dan Berbahaya (B3) berupa Fly Ash $80 \%$ dan Bottom Ash $20 \%$ (Aida et al., 2018). Pengelolaan limbah abu pembakaran batubara kebanyakan masih dilakukan dengan cara landfill (Aida et al., 2018). Cara itu sangat membahayakan bagi ekosistem sekitar. Diperkirakan bahwa produksi fly ash batubara di seluruh dunia lebih dari 500 juta ton per tahun (Syafri et al., 2016). Batubara merupakan bahan bakar fosil paling kotor, sehingga dengan meningkatnya penggunaan batubara sebagai sumber energi, perlu mendapat perhatian mengenai dampak lingkungan yang ditimbulkan (Suwarna, 2016).

Fly ash mengandung unsur oksida dominan berupa $\mathrm{SiO}_{2}$ 50,60\%; $\mathrm{Al}_{2} \mathrm{O}_{3} 21,90 \% ; \mathrm{SO}_{3} 12,20 \%$ dan $\mathrm{Fe}_{2} \mathrm{O}_{3} 7,76 \%$ (Firman, 2020). Fly ash kaya akan oksida aluminium dan oksida besi yang merupakan bahan baku penting untuk pembuatan koagulan (Fan et al., 2005). Koagulan berbasis oksida Al dan Fe sudah banyak dipakai dalam proses pengolahan air, karena mampu mengikat partikel-partikel koloid di dalam air sehingga membentuki flok (Safutra et al., 2017). Berdasarkan kandungan tersebut, fly ash dapat dikelola dengan menggunakan konsep reverse logistic sehingga tidak menimbulkan kerusakan ekosistem lingkungan.

Reverse logistics mencakup serangkaian proses yang melibatkan pengembalian produk, perbaikan, remanufaktur, daur ulang dan pembuangan produk kadaluarsa/bekas (Aneesh \& Kumar, 2020). Reverse logistics telah menjadi bidang yang penting bagi semua organisasi dengan meningkatnya kepedulian terhadap lingkungan, undang-undang, tanggung jawab sosial perusahaan, dan daya saing yang berkelanjutan (Agrawal et al., 2015). Penerapan konsep reverse logistics dengan baik, dapat memberi keuntungan lingkungan, sosial serta ekonomis (Zaroni, 2017).

Penelitian ini bertujuan membuat sintesis koagulan dari fly ash batubara yang nantinya dapat digunakan pada unit effluent treatment di PT. Petrokimia Gresik, dengan menerapkan konsep reverse logistics. Pemilihan konsep ini sangat cocok untuk solusi penanganan limbah fly ash batubara dan juga untuk pemenuhan kebutuhan koagulan, dengan cara mendaur ulang limbah fly ash untuk dijadikan umpan balik dalam proses di unit lainnya, yang sebelumnya disimpan di landfill yang dapat berdampak pada pencemaran lingkungan dan masalah sosial. Sehingga dapat membentuk aliran closed loop dalam proses perusahaan. Selain dapat memberi keuntungan secara ekonomis, perusahaan juga bisa memperhatikan etika lingkungan dalam 
proses bisnis sehingga peran industri dalam sustainable development dapat berjalan sesuai yang diharapkan.

\section{METODE PENELITIAN}

Bahan yang digunakan dalam penelitian ini yaitu Fly Ash Batubara, air limbah di unit Effluent Treatment PT. Petrokimia Gresik. Sedangkan reagen yang diperlukan adalah Asam sulfat $\left(\mathrm{H}_{2} \mathrm{SO}_{4}\right)$ 1:1, Aqua demineralisasi, Asam nitrat $\left(\mathrm{HNO}_{3}\right)$ 1:2, Natrium Carbonat $\left(\mathrm{Na}_{2} \mathrm{CO}_{3}\right)$ p.a, Asam borat $\left(\mathrm{H}_{3} \mathrm{BO}_{3}\right)$ p.a, Suppressor Al dan Standar Al.

Alat-alat yang digunakan dalam penelitian ini adalah gelas beker, gelas ukur, labu ukur, neraca analitik, cawan platina, pipet volume, pipet ukur, balb pipet, botol semprot, spatula, pengaduk, magnet pengaduk, cawan porselen, corong, desikator, kertas saring whatman 41, centrifuge, Atomic Absorption Spectrometry (AAS), turbidimeter, oven, dan pompa vakum. Data yang diperlukan dalam penelitian ini yaitu data limbah hasil pembakaran batubara, dan data kebutuhan koagulan.

Penelitian ini adalah menggunakan konsep reverse logistics dengan sistem closed loop. Dalam menerapkan konsep reverse logistics, peneliti mempelajari alur proses di UBB, dari bahan baku hingga menjadi produk dan menghasilkan limbah. Limbah tersebut akan didaur ulang dan dimanfaatkan untuk bahan masukan proses di unit lain, sehingga dapat membentuk sistem closed loop. Closed loop system merupakan metode untuk membuat rantai produksi, pemasaran maupun disposal menjadi siklus tertutup (Loice et al., 2016).

Unit produksi satu PT Petrokimia Gresik dengan yang lain, saling mempengaruhi aliran proses produksi. PT Petrokimia Gresik yang dikenal sebagai perusahaan pupuk nasional, juga memproduksi beragam produk non-pupuk yang digunakan sebagai bahan baku produksi pupuk dan sebagian dijual di pasaran. Penelitian ini selain membuat koagulan dari limbah sisa pembakaran batubara yaitu fly ash, juga diharapkan bisa memanfaatkan produk yang dihasilkan untuk masukan proses di unit lain di dalam perusahaan. Untuk itu, peneliti mempelajari secara luar proses produksi perusahaan sehingga dapat menemukan solusi yang tepat untuk pemanfaatan produk hasil sintesis.

Proses penelitian pada sintesis koagulan dilakukan dalam dua tahapan dengan metode eksperimen. Pertama, pembuatan koagulan padat (serbuk) dari fly ash batubara yang direaksikan dengan Asam sulfat $\left(\mathrm{H}_{2} \mathrm{SO}_{4}\right)$ serta memvariasikan rasio pencampuran untuk mendapatkan hasil yang optimal. Tahap kedua, pengaplikasian produk sintesis koagulan pada proses Effluent Treatment di PT Petrokimia Gresik.

Proses evaluasi dalam penelitian ini adalah menghitung potensi penghematan/keuntungan dari aspek sosial, lingkungan dan ekonomis dari penerapan konsep reverse logistics dengan sistem closed loop.

\section{HASIL DAN PEMBAHASAN}

Unit utilitas batubara PT. Petrokimia Gresik memiliki kapasitas 32 Megawatt. Di unit utilitas batubara memiliki unit 2 boiler yang menghasilkan 300 ton/jam steam, yang membutuhkan 450-600 ton/hari batubara dan menghasilkan rata-rata 20 ton/hari limbah fly ash dengan kondisi pabrik normal operasi.

Dalam alur proses UBB menghasilkan beberapa macam polusi lingkungan diantaranya: debu dari proses handling, emisi gas pembakaran dan limbah hasil pembakaran lainnya yang berupa fly ash \& bottom ash. Dari beberapa macam limbah tersebut, salah satunya fly ash akan dimanfaatkan untuk menjadi koagulan, sehingga dapat memberikan nilai tambah bagi perusahaan dari segi lingkungan, sosial maupun ekonomis.

Sistem closed loop pada penelitian ini, memperhatikan limbah hasil pembakaran batubara (fly ash) untuk bisa dimanfaatkan dan dimasukkan ke dalam aliran produksi di unit lainnya. Diharapkan dengan diolahnya fly ash menjadi koagulan bisa menutup lingkaran produksi, sehingga perusahaan dapat mengelola limbah yang dihasilkan dari proses produksi dan meminimalisir pencemaran lingkungan. Setelah pengolahan fly ash menjadi koagulan, aliran proses produksi di PT Petrokimia Gresik berubah seperti pada Gambar 1.

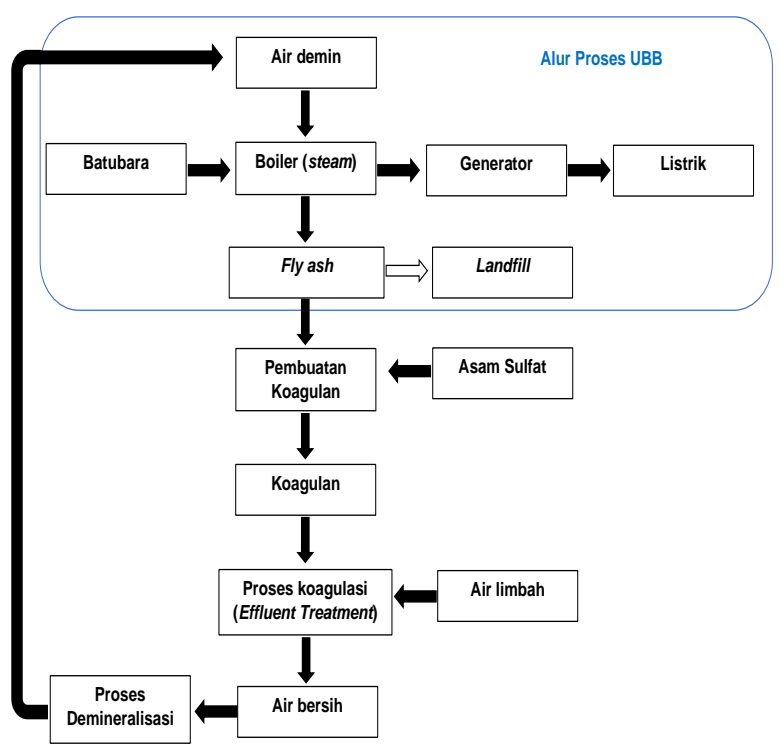

Gambar 1. Skema Closed Loop System 
Koagulan hasil sintesis dapat dijadikan bahan masukan pada proses koagulasi di unit effluent treatment yang menghasilkan air bersih. Air bersih kemudian diolah pada unit demineralisasi untuk menghilangkan kandungan mineral pada air, kemudian dijadikan sebagai air masukan boiler di UBB.

\section{Sintesis Koagulan dari Fly Ash Batubara dan Pengaplikasian}

Fly ash yang digunakan dalam penelitian ini berasal dari sisa pembakaran batubara di unit UBB. Fly ash yang didapatkan berupa serbuk halus yang terdapat senyawa $\mathrm{Al}_{2} \mathrm{O}_{3}$ dengan kadar sebesar 20,56\%. Senyawa $\mathrm{Al}_{2} \mathrm{O}_{3}$ direaksikan dengan asam sulfat $\left(\mathrm{H}_{2} \mathrm{SO}_{4}\right)$ untuk membentuk senyawa aluminium sulfat $\mathrm{Al}_{2}\left(\mathrm{SO}_{4}\right)_{3}$ sebagai koagulan (Fan et al., 2005). Berikut reaksi yang terjadi:

$\mathrm{Al}_{2} \mathrm{O}_{3}(\mathrm{~s})+3 \mathrm{H}_{2} \mathrm{SO}_{4}(\mathrm{I}) \rightarrow \mathrm{Al}_{2}\left(\mathrm{SO}_{4}\right)_{3}(\mathrm{~s})+3 \mathrm{H}_{2} \mathrm{O}(\mathrm{I})$

Selain itu, tujuan mereaksikan dengan asam sulfat $\left(\mathrm{H}_{2} \mathrm{SO}_{4}\right)$ untuk menghancurkan lapisan permukaan partikel fly ash yang berbentuk rantai glassy yang sangat rapat dan stabil, sehingga dapat mengeluarkan gugus aktif yang berada di dalamnya (Susilo \& Sulistyawati, 2019).

Sampel limbah yang digunakan berasal dari TK 6616 (Neutralise Water) yang merupakan tahapan sebelum proses koagulasi berdasarkan alur proses di unit effluent treatment. TK 6616 merupakan hasil dari proses penetralan kadar keasaman (Tabel 1). Karena sumber limbah yang diterima di unit effluent treatment mempunyai karakteristik derajat keasaman $(\mathrm{pH})$ rendah. Nilai $\mathrm{pH}$ merupakan salah satu faktor keberhasilan proses koagulasi, rentang $\mathrm{pH}$ yang efektif berada dikisaran 5,5-8,0 (Rachmawati \& Iswanto, 2009). Pada kisaran $\mathrm{pH}$ 5-9 partikel di dalam air membawa muatan negatif yang mengakibatkan koloid stabil dan tahan terhadap agregasi (Muruganandam et al., 2017).

Tabel 1. Data Hasil Pengujian Karakterisasi Air Limbah

\begin{tabular}{cccc}
\hline Sumber & pH & Turbiditas & TSS \\
\hline TK 6616 & 7,3 & 806 & 3124 \\
\hline
\end{tabular}

Koagulan hasil dari reaksi antara fly ash dengan asam sulfat kemudian dilakukan pengujian untuk menentukan dosis optimum pada air limbah. Terdapat dua tahapan pengujian. Pertama, dengan memvariasikan rasio pencampuran fly ash dengan asam sulfat dalam proses pembuatan koagulan. Pengujian dengan menggunakan sampel limbah. Rasio pencampuran optimum diperoleh pada variasi 1:2 dengan nilai turbiditas 14,0 NTU. Kedua, variasi dosis berdasarkan hasil rasio optimum (Tabel 2).
Tabel 2. Data Pengujian Variasi Rasio Pencampuran

\begin{tabular}{ccc}
\hline No. & Rasio & Turbiditas (NTU) \\
\hline 1. & $1: 2$ & 14,0 \\
2. & $1: 3$ & 15,8 \\
3. & $1: 4$ & 19,0 \\
4. & $1: 5$ & 20,2 \\
5. & $1: 7$ & 29,1 \\
\hline
\end{tabular}

Dosis koagulan yang paling optimum dalam meningkatkan kualitas air limbah di unit effluent treatment adalah variasi nomor 1 dengan pemakaian dosis koagulan 0,5 g/L (Tabel 3). Air limbah sebelum dan setelah pengujian tersaji pada Gambar 2.

Tabel 3. Data Pengujian Variasi Dosis Koagulan Optimum

\begin{tabular}{cccc}
\hline No. & Dosis (g/L) & $\begin{array}{c}\text { Turbiditas } \\
\text { (NTU) }\end{array}$ & TSS \\
\hline 1. & 0,50 & 10,6 & 81 \\
2. & 0,75 & 11,2 & 113 \\
3. & 1,00 & 15,2 & 114 \\
4. & 1,25 & 18,2 & 110 \\
5. & 1,75 & 22,1 & 160 \\
\hline
\end{tabular}

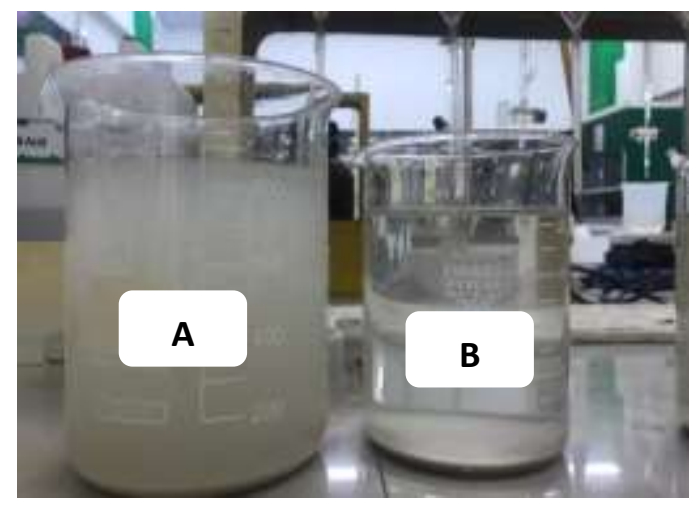

Gambar 2. Air Limbah Sebelum dan Sesudah Pengujian ( $A=$ Air TK 6616; $B=$ Air Hasil Pengujian)

\section{Evaluasi Perhitungan Hasil Penelitian}

Perhitungan potensi penghematan dari penerapan konsep reverse logistics di PT. Petrokimia Gresik dilihat dari beberapa aspek, seperti aspek lingkungan, sosial maupun ekonomis.

\section{Evaluasi Sintesis Koagulan dan Perbandingan dengan Penelitian Sebelumnya}

Dosis pemakaian koagulan fly ash pada penelitian ini optimum pada dosis paling rendah dari 5 variabel yang diuji yaitu $0,5 \mathrm{~g} / \mathrm{L}(500 \mathrm{ppm})$. Dengan hasil itu, menunjukkan semakin banyaknya pemakaian dosis koagulan, persentase penurunan turbiditas dan TSS semakin rendah. 
Hal ini sejalan dengan penelitian Syafri et al. (2016) yang menyatakan bahwa gagalnya proses koagulasi disebabkan oleh berlebihnya muatan ion dari koagulan fly ash yang ditambahkan, dari pada ion yang dibutuhkan dalam air limbah untuk membentuk flok, sehingga terjadi deflokulasi yang mengakibatkan partikel-partikel di dalam air limbah tidak mengendap.

Limbah fly ash yang dihasilkan saat kondisi pabrik normal operasi yaitu sebanyak 20 ton per hari, dapat diolah kembali untuk dijadikan koagulan yang nantinya dapat digunakan sebagai bahan masukan pada proses unit effluent treatment di lingkungan perusahaan. Dari 20 ton fly ash dengan konsentrasi $\mathrm{Al}_{2} \mathrm{O}_{3}$ sebesar $20,56 \%$, membutuhkan 7,89 ton asam sulfat dengan konsentrasi 1:1. Proses tersebut dapat menghasilkan koagulan sebanyak 13,68 ton.

\section{Evaluasi Aspek Ekonomis}

Kebutuhan koagulan di PT Petrokimia Gresik dengan 2 unit effluent treatment rata-rata sebesar 1 ton per hari. Dalam kondisi normal operasi, 2 unit effluent treatment tersebut dapat menghasilkan produk air dari pengolahan air limbah sebesar $2800 \mathrm{~m}^{3}$ per hari. Air hasil olahan limbah, sebagian besar digunakan sebagai air masukan proses pabrik, sebagian untuk water cleaning dan sebagian lainnya dialirkan ke laut.

Dari 20 ton fly ash apabila diolah menjadi koagulan, membutuhkan asam sulfat sebanyak 7,89 ton dengan biaya $\mathrm{Rp} 5.325 .750$, asam sulfat yang digunakan merupakan produksi PT Petrokimia Gresik sendiri. Proses pembuatan koagulan dapat menghasilkan koagulan sebanyak 13,68 ton atau seharga $\mathrm{Rp} 54.720 .000$ dengan harga koagulan Rp 4.000 per kg. Apabila hasil penelitian ini dilaksanakan, perusahaan berpotensi mendapatkan keuntungan sebesar $\mathrm{Rp}$ 49.394.250 per hari.

\section{Evaluasi Aspek Sosial dan Lingkungan}

Penerapan konsep reverse logistics pada limbah hasil pembakaran batubara yang akan diolah kembali untuk dijadikan koagulan, dapat berdampak pada aliran proses antar unit produksi yang akan membentuk sistem closed loop. Konsep ini dapat meminimalisir pencemaran lingkungan yang disebabkan oleh limbah fly ash batubara di PT Petrokimia Gresik. Implementasi konsep ini juga dapat meminimalisir aspek sosial yang timbul di masyarakat sekitar dengan adanya emisi partikel fly ash batubara yang berterbangan sehingga menimbulkan pencemaran kualitas udara.

\section{KESIMPULAN}

Pengelolaan limbah fly ash batubara menjadi koagulan padat dengan menerapkan konsep reverse logistics, menjadi alternatif solusi bagi perusahaan untuk meminimalisir pencemaran lingkungan yang dihasilkan oleh proses produksi. Hasil pengolahan fly ash menjadi koagulan, berhasil menutup aliran proses yang sebelumnya terputus pada limbah fly ash batubara dengan penerapan sistem closed loop. Proses ini dapat memperbaiki proses landfill (Aida et al., 2018), dimana proses landfill dapat membahayakan bagi ekosistem sekitar.

Rasio pencampuran optimum antara fly ash kadar $\mathrm{Al}_{2} \mathrm{O}_{3}$ sebesar $20,56 \%$ dengan $\mathrm{H}_{2} \mathrm{SO}_{4} 1: 1$ dalam pembuatan koagulan didapatkan rasio 1:2. Dosis optimum pemakaian koagulan dalam penelitian ini pada air limbah di TK 6616 (neutralis water) yaitu sebesar $0,5 \mathrm{~g} / \mathrm{L}(500 \mathrm{ppm})$ dengan penurunan turbiditas sebesar $98,68 \%$ dan penurunan TSS sebesar $97,41 \%$. Koagulan yang dihasilkan sebanyak 13,68 ton dengan potensi keuntungan dari penerapan hasil penelitian ini sebesar Rp 49.394.250 per hari.

Penelitian ini menggunakan asam sulfat dengan konsentrasi 1:1 sebagai aktivator, dengan tujuan untuk mempermudah proses pengenceran apabila diterapkan pada skala pabrik dengan menggunakan asam sulfat pekat produksi PT Petrokimia Gresik. Peluang penelitian lanjutan adalah perlu menggunakan asam sulfat encer sebagai aktivator agar dapat diketahui tingkat efektifitas produk yang dihasilkan pada proses koagulasi di unit effluent treatment PT Petrokimia Gresik. Perusahaan perlu melakukan analisis studi kelayakan untuk menyelaraskan antara proyek pengembangan produksi koagulan dengan strategi bisnis perusahaan.

\section{DAFTAR PUSTAKA}

Agrawal, S., Singh, R. K., \& Murtaza, Q. (2015). A literature review and perspectives in reverse logistics. Resources, Conservation and Recycling, 97, 76-92. https://doi.org/https://doi.org/10.1016/j.resco nrec.2015.02.009

Aida, E. R., Lisha, S. Y., \& Puty, Y. (2018). Pemanfaatan Limbah Abu Batubara (Fly Ash) di PLTU Ombilin Sebagai Koagulan. Jurnal Pendidikan Teknologi Kejuruan, 1(3), 125-131. https://doi.org/10.24036/jptk.v1i3.2223

Aneesh, S., \& Kumar, N. A. (2020). Reverse Logistic Network for used Refrigerators. International Journal of Research in Engineering, Science and Management, 2(6), 280-283. https://www.jiresm.com/Vol.2_2019/Vol2_Is s6_June19/IJRESM_V2_I6_77.pdf

Baiquni, M. (2009). Revolusi industri, ledakan penduduk dan masalah lingkungan. Jurnal 
Sains \&Teknologi Lingkungan, 1(1), 38-59. https://doi.org/10.20885/jstl.vol1.iss1.art3

Fajariah, M., \& Suryo, D. (2020). Sejarah Revolusi Industri di Inggris Pada Tahun 1760-1830. HISTORIA : Jurnal Program Studi Pendidikan Sejarah, 8(1), 77-94. https://doi.org/10.24127/hj.v8i1.2214

Fan, M., Brown, R. C., Wheelock, T. D., Cooper, A. T., Nomura, M., \& Zhuang, Y. (2005). Production of a complex coagulant from fly ash. Chemical Engineering Journal, 106(3), 269-277.

https://doi.org/https://doi.org/10.1016/j.cej.2 004.12 .044

Firman, F. (2020). Analisis Kandungan Logam Berat Abu Batubara PLTU Bangko Barat Kab. Muara Enim Sumatera Selatan. Journal Of Science And Engineering, 3(1), 10-16. https://ejournal.unkhair.ac.id/index.php/josa e/article/view/2070

Keraf, A. S. (2010). Etika lingkungan hidup. Jakarta: Kompas. https://books.google.co.id/books?id=gW6q GODQ2 cC

Loice, R., Arthaya, B. M., \& Prasetyo, H. (2016). Penerapan Inverse Manufacturing dalam Penanganan Produk Lampu Hemat Energi. Jurnal Rekayasa Sistem Industri, 5(1), 3138.

https://doi.org/10.26593/jrsi.v5i1.1911.31-38

Muruganandam, L., Saravana Kumar, M. P., Jena, A., Gulla, S., \& Godhwani, B. (2017). Treatment of waste water by coagulation and flocculation using biomaterials. IOP Conference Series: Materials Science and Engineering, 263(3), 032006. https://doi.org/10.1088/1757-
899X/263/3/032006

Rachmawati, S. W., \& Iswanto, B. (2009). Pengaruh $\mathrm{Ph}$ Pada Proses Koagulasi Dengan Koagulan Aluminum Sulfat Dan Ferri Klorida. Indonesian Journal Of Urban And Environmental Technology, 5(2), 40-45. https://trijurnal.lemlit.trisakti.ac.id/urbanenvir otech/article/view/676

Safutra, Y., Amin, B., \& Anita, S. (2017). Potensi Limbah Abu Layang (Coal Fly Ash) Sebagai Koagulan Cair Dalam Pengolahan Air Gambut. Dinamika Lingkungan Indonesia, 4(2), 99-108. https://dli.ejournal.unri.ac.id/index.php/DL/ar ticle/view/4506

Susilo, N. A., \& Sulistyawati, N. (2019). Penggunaan asam sulfat sebagai aktivator fly ash dalam aplikasi proses koagulasi pada pengolahan limbah cair industri pulp dan kertas. Jurnal Vokasi Teknologi Industri (JVTI), 1(1), 1-9. https://doi.org/10.36870/jvti.v1i1.39

Suwarna, E. (2016). Perkembangan Teknologi Batubara Bersih Berwawasan Lingkungan. Jurnal Teknologi Lingkungan, 12(1), 25-34. https://doi.org/10.29122/jtl.v12i1.1259

Syafri, R., Nazara, F. R., \& Nasution, H. (2016). Analisa $\mathrm{pH}$, TSS dan Warna Dalam Proses Pengolahan Air Limbah Pulp Dan Kertas Menggunakan Koagulan Fly Ash. 1th Celscitech, $17-20$. http://digilib.mercubuana.ac.id/manager/t!@ file_artikel_abstrak/Isi_Artikel_6425595796 78.pdf

Zaroni. (2017). Reverse Logistics. https://supplychainindonesia.com/reverselogistics/ 